\title{
Potential of Non-chemical Control Strategies for Reduction of Soil Insect Damage in Sweetpotato
}

\author{
J.M. Schalk ${ }^{1}$, J.R. Bohac ${ }^{2}$, and P.D. Dukes ${ }^{3}$ \\ U.S. Department of Agriculture, Agricultural Research Service, U.S. Vegetable Laboratory, 2875 Savannah \\ Highway, Charleston, SC 29414
}

W.R. Martin ${ }^{4}$

Biosys, 1057 East Meadow Circle, Palo Alto, CA 94303

Additional index words. Ipomoea batatas, parasitic nematode, plant resistance, biological control, wireworms, flea beetles, grubs, cucumber beetles

\begin{abstract}
This 2-year study was conducted to determine if soil insect damage could be reduced in sweetpotato [Ipomoea batatas (L.) Lam] by treatment with an insecticide (fonofos) and/or a parasitic nematode (Steinernema carpocapsae Weiser), in conjunction with sweetpotato cultivars that differed in susceptibility to soil insect damage. Analysis of field data for the first year showed that the parasitic nematode provided significant damage protection of sweetpotato from wireworms (Conoderus spp.), Diabrotica sp., Systena sp., and sweetpotato flea beetle (Chaetocnema confinis Crotch), but not from grubs (Plectris aliena Chapin; Phyllophaga ephilida Say). In this same test, fonofos used alone provided protection against wireworm- Diabrotica-Systena (WDS complex) damage. In the second test, the nematode did not provide soil insect protection for the WDS complex, but fonofos did reduce damage for these insects. Poor efficacy in the second test with the nematode probably was due to high rainfall, which saturated the soil. Resistant cultivars provided good protection for all three categories of damage. When used with the insect-susceptible check 'SC 1149-19', the nematode or fonofos treatments provided better control for all insect categories in the first test. In both years, much higher control of damage by all insect classes was achieved by the use of resistant cultivars in combination with the nematode and/or fonofos treatment (64\% higher crop protection than the susceptible check line). Chemical name used: O-ethyl-S-phenylethylphosphonodithioate [fonofos (Dyfonate 10G)].
\end{abstract}

Sweetpotato roots often are damaged by a complex of insects, including the larvae of wireworms; cucumber beetles (Diabrotica balteata LeConte and D. undecimpunctata howardi Barber); Systena spp. (S. blanda Melsheimer, S. elongata Fabricius, S. frontalis Fabricius) (these three groups are known as the "WDS complex" because their damage is similar); sweetpotato flea beetle (SPFB); and grubs (Schalk 1984, Schalk and Jones 1985). Insecticides have been the main defense in reducing damage by these pests but control with chemicals has been unreliable since the persistent chlorinated hydrocarbons were deregistered. Therefore, alternative control methods such as biological control, less-persistent insecticides, and resistant cultivars are needed to maintain the present level of sweetpotato production in the United States (Schalk et al., 1991). Reducing soil insect damage to sweetpotato roots has been achieved through the use of a parasitic nematode (Jansson et al. 1990, 1991), resistant cultivars (Jones et al., 1983, 1985, 1987a, 1987b, 1989), and insecticides (Chalfant et al., 1990). The purpose of this study was to determine if soil insect damage to sweetpotato roots could be reduced by employing a parasitic nematode with or without a nonpersistent insecticide, in conjunction with resistant sweetpotato cultivars.

\section{Materials and Methods}

Efficacy of the nematode (Steinernema carpocapsae, all strains)

Received for publication 10 Aug. 1992. Accepted for publication 2 Dec. 1992. Mention of a pesticide in this paper does not constitute a recommendation for use by the USDA nor does it imply registration under the Federal Insecticide, Fungicide, and Rodenticide Act as amended. The cost of publishing this paper was defrayed in part by the payment of page charges. Under postal regulations, this paper therefore must be hereby marked advertisement solely to indicate this fact.

'Research Entomologist, retired.

Research Geneticist; to whom correspondence should be addressed.

${ }^{3}$ Research Plant Pathologist.

${ }^{4}$ Senior Entomologist. on $D$. balteata was evaluated by exposing late-first and earlysecond instars to nematode (infective juveniles) inoculations in the laboratory before field experiments were conducted. Nematodes were applied $\left(26.2 / \mathrm{cm}^{2} ; 2.5\right.$ billion/ha) to $800 \mathrm{~g}$ of blasting sand $(0.23 \times 0.15 \mathrm{~mm}$ in diameter) moistened with distilled water $(200$ $\mathrm{ml}$ ); the contents were mixed by hand. Fifty insect larvae and $25 \mathrm{~g}$ of germinating wheat then were added (Schalk et al., 1986). The control was the same except that no nematodes were applied. The test was replicated four times. The number of emerging $D$. balteata adults was recorded.

Two field tests were conducted at the U.S. Vegetable Laboratory, Charleston, S.C., one in 1990 and another in 1991, on Lynchburg loamy fine sand.

The cultivars with resistance to soil insect damage used in these tests were 'Excel', 'Regal', 'Resisto', and 'Southern Delite' (Jones et al., 1983, 1985, 1987a, 1989). The cultivar susceptible to all damage categories was 'SC 1149-19', and the popular commercial cultivars were 'Jewel' and 'Centennial' (Jones et al., 1987b). Yield data (root fresh weight) were recorded for both tests.

Nematode or insecticide application (Test 1, 1990). Rooted vine cuttings of resistant and susceptible sweetpotato cultivars were transplanted on 5 May 1990. The research plots were three rows across by $3.1 \mathrm{~m}$ long and $91 \mathrm{~cm}$ apart, containing 10 plants $(30$ $\mathrm{cm}$ apart) of a single cultivar per row. A buffer row of a susceptible cultivar was planted on each side of the three-row plot. The center row of each plot was harvested 126 days after transplanting. The soil insecticide fonofos (Dyfonate 10G) was applied by hand (2.2 $\mathrm{kg}$ a.i./ha) at planting and at root enlargement (2 July). The parasitic nematode, S. carpocapsae, was applied three times (2 July, 2 Aug., and 4 Sept.) at 2.5 billion infective juveniles/ha. To enhance nematode survival and efficacy, each inoculation was preceded by irrigation $(2.5 \mathrm{~mm})$ or rainfall. To determine insect population densities, soil samples $\left(3540 \mathrm{~cm}^{3}\right)$ were collected $(4$ June, 30 July, and 29 Aug.) from several roots on the outside rows 
of the treatment plot. Insects were separated from the soil samples by washing samples gently with water and filtering the soil through a series of screens that retained the insects. The insects were identified by observation through a dissecting microscope. To determine the residual activity of fonofos and nematode treatments, three random soil samples per plot $\left(63 \mathrm{~cm}^{3} /\right.$ replicate $)$ were collected from the center row on three dates $\approx 3$ weeks after each nematode application (23 July, 23 Aug., and 24 Sept.) from the susceptible cultivar (SC 1149-19). These moist soil samples were bioassayed in the laboratory by exposing 10 to 50 late-first or early-second instars of $D$. balteata [applied to soil surface and fed $25 \mathrm{~g}$ of germinating wheat (Schalk, 1986)] per replication and recording the number of survivors after 7 to 15 days.

Nematode plus insecticide application (Test 2, 1991). Rooted vine cuttings of resistant and susceptible sweetpotato cultivars were transplanted on 5 May 1991. Each plot was designed as in the first test. The center row of each plot was harvested on 12 Sept.119 days after transplanting. Fonofos was applied as in Test 1 on 5 May and 9 July. The nematode was applied at 2.5 and 7.5 billion infective juveniles/ha. An additional treatment consisting of the nematode ( 2.5 billion infective juveniles/ha) in combination with fonofos $(2.2 \mathrm{~kg}$ a.i./ha) was included. The nematodes were applied on 28 June, 26 July, and 26 Aug. Rainfall or irrigation $(2.5 \mathrm{~mm})$ preceded the nematode inoculations to enhance survival. Determination of insect population densities and identifications were the same as in Test 1, with samples collected on 7 July and 28 Aug. Residual activity of fonofos and the nematode on survival of young larvae of $D$. balteata (20/replicate) was determined as in the previous test on 4 and 24 Sept. Root damage by the wirewormDiabrotica-Systena complex (WDS) was rated for both years as: a) number of roots with injury per total number of roots $\times 100=$ percentage of roots injured; and $b$ ) a severity index by assigning a score based on the number of feeding scars (no scars $=0$, one to five scars $=1$, six to 10 scars $=2$, more than 10 scars $=4$ ). Sweetpotato flea beetle (SPFB) and grub damage were recorded as percentages of roots injured (Jones et al., 1979).

Percentage field control provided by the individual treatments and treatments in combination (nematode, fonofos, or cultivars) were compared with the controls (no nematode or fonofos; 'SC 1149-19'). Percentage field control was rated as $\mathrm{a}-\mathrm{b} / \mathrm{a} \times 100$, where $\mathrm{a}=$ percentage of damaged roots of the control or 'SC 114919 ' and $b=$ percentage of damaged roots from the three treatments: fonofos, nematode, or cultivars (Schalk et al., 1986).

The design was a randomized complete block with four replications for both laboratory and field tests. Laboratory tests were conducted at $21.6 \pm 1.8 \mathrm{C}$ and $53 \% \pm 17 \% \mathrm{RH}$.

\section{Results and Discussion}

Nematode efficacy. In the laboratory tests where nematode populations simulated field inoculations, $99.3 \%$ mortality of $D$. balteata resulted from nematode parasitism, while mortality in the control without nematodes was only $20 \%$.

Field insectpopulations. Field population counts of larvae were combined for all sample dates because they contributed to the final root injury. In Tests 1 and 2, the nematode did not reduce larval counts for wireworms and Diabrotica sp.; however, in the fonofos treatment, fewer insect larvae were observed from soil samples (number of larvae: Test 1 , nematode $=2.3$, control $=2.5$, fonofos $=0.7$; Test 2 , nematode $=0.9$ and 1.1 , control $=1.4$, nematode + fonofos $=0.2$, fonofos $=0.3$ ). No differences in wireworm and Diabrotica populations were observed between the resistant and susceptible cultivars for either test (Test 1 , mean $1.8 \pm 0.58 \mathrm{SD}$; Test
$2,0.87 \pm 0.3 \mathrm{SD}$ ). Overall, the wireworm and Diabrotica (WDS complex) populations were much lower in Test 2 than in Test 1 .

Field soil bioassays. When D. balteata larvae were exposed to field-treated soil from Test 1, significantly higher mortality resulted from the fonofos treatment (mean 59.8\% $\pm 10.8 \% \mathrm{SD}$ ), compared to the nematode treatment and control. The nematode and control treatments were not significantly different (means were $20.5 \% \pm 5.8 \%$ sD and $18.6 \% \pm 8.1 \%$ SD, respectively). The residual activity of fonofos was 12 weeks in the first test. In Test 2 , no differences were found in insect mortality for field soil treated with the nematode, fonofos, or control. The lack of insecticidal activity in Test 2 can be attributed to leaching of the chemical from the root zone because of high rainfall (66 vs. $47 \mathrm{~cm})$.

Field efficacy of nematode and/or fonofos. The nematode treatment effectively reduced WDS and SPFB damage in Test 1. Fonofos reduced WDS damage, but not SPFB damage. In Test 2, fonofos treatments were superior to the nematode and the control in reducing WDS and SPFB damage (Table 1).

Cultivar efficacy. Insect damage for all categories (WDS, SPFB, and grubs) differed between years, but in both years, resistant cultivar reaction was similar when compared to the susceptible control ('SC 1149-19') (Table 2). 'Regal', 'Resisto', 'Southern Delite', and 'Excel' displayed higher resistance to the WDS complex than 'Jewel' or 'Centennial', which were intermediate. All cultivars, except SC 1149-19, were resistant to SPFB damage. Grub damage to cultivars in Test 1 was extremely low, making interpretation of the analysis impossible. However, grub damage was higher in Test 2 and higher resistance to this damage was observed in 'Regal' and 'Resisto' than in the susceptible

Table 1. Efficacy of insecticide (fonofos) and an entomopathogenic nematode (Steinernema carpocapsae) on reducing soil insect damage in sweetpotato cultivars, 1990 and 1991.

\begin{tabular}{|c|c|c|c|c|}
\hline Treatment & $\begin{array}{c}\text { WDS }^{z} \\
\text { injury (\%) }\end{array}$ & $\begin{array}{l}\text { WDS }^{y} \\
\text { index }\end{array}$ & $\begin{array}{c}\text { SPFB }^{\mathrm{x}} \\
\text { injury }(\%)\end{array}$ & $\begin{array}{c}\text { Grubs }^{w} \\
\text { injury }(\%)\end{array}$ \\
\hline \multicolumn{5}{|c|}{$1990($ Test 1) } \\
\hline Nematode $2.5 b^{v}$ & $41.1 b^{u}$ & $0.60 \mathrm{~b}$ & $11.4 \mathrm{~b}$ & $1.4 \mathrm{NS}$ \\
\hline Fonofos ${ }^{t}$ & $43.6 \mathrm{ab}$ & $0.63 \mathrm{~b}$ & $14.2 \mathrm{a}$ & $3.2 \mathrm{NS}$ \\
\hline Check $^{\mathrm{s}}$ & $48.6 \mathrm{a}$ & -- & $15.2 \mathrm{a}$ & $0.8 \mathrm{NS}$ \\
\hline LSD (5\% level) & 5.9 & 0.14 & 3.1 & 2.7 \\
\hline \multicolumn{5}{|c|}{1991 (Test 2) } \\
\hline Nematode $2.5 b b^{v}$ & $33.5 \mathrm{a}$ & $0.46 \mathrm{a}$ & $12.4 \mathrm{a}$ & $22.9 \mathrm{NS}$ \\
\hline Nematode $7.5 b^{v}$ & $37.1 \mathrm{a}$ & $0.49 \mathrm{a}$ & $11.9 \mathrm{a}$ & $27.3 \mathrm{NS}$ \\
\hline $\begin{array}{l}\text { Nematode } 2.5 b^{v}+ \\
\text { fonofos }^{\mathrm{t}}\end{array}$ & $19.3 \mathrm{~b}$ & $0.20 \mathrm{~b}$ & $9.8 \mathrm{ab}$ & $28.2 \mathrm{NS}$ \\
\hline Fonofos ${ }^{t}$ & $22.7 \mathrm{~b}$ & $0.27 \mathrm{~b}$ & $7.7 \mathrm{~b}$ & $21.3 \mathrm{NS}$ \\
\hline Check $^{\mathrm{s}}$ & $32.9 \mathrm{a}$ & $0.52 \mathrm{a}$ & $13.1 \mathrm{a}$ & $17.6 \mathrm{NS}$ \\
\hline LSD (5\% level) & 8.9 & 0.12 & 3.9 & 11.7 \\
\hline
\end{tabular}

${ }^{\mathrm{z}}$ Wireworms (Conoderus sp.), Diabrotica sp. (D. balteata LeConte, $D$. undecimpunctata howardi Barber), and Systena sp. (S. blanda Melsheimer, S. elongata Fabricius, $S$. frontalis Fabricius).

yIndex numbers: $0=$ no scars, $1=$ one to five scars, $2=$ six to 10 scars, 4 $=$ more than 10 scars.

${ }^{x}$ Sweetpotato flea beetle (C. confinis Crotch).

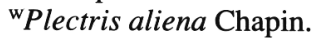

'Nematode applied three times each season (1990: 2 July, 2 Aug., and 4 Sept.; 1991: 28 June, 26 July, and 26 Aug.) at 2.5 and 7.5 billion/ha.

uMean separation within column and year (arcsin transformation; no transformation conducted on WDS damage index) by LSD test, $P \leq 0.05$, NS $=$ nonsignificant .

${ }^{\mathrm{t}}$ Fonofos at $2.2 \mathrm{~kg}$ a.i./ha applied at planting and at root enlargement (1990: 5 May and 2 July; 1991: 5 May and 9 July, respectively).

${ }^{\mathrm{s}}$ No fonofos or nematode applications. 
Table 2. Soil insect damage to sweetpotato cultivars for all treatment combinations (nematode, fonofos) in 1990 and 1991.

\begin{tabular}{|c|c|c|c|c|c|}
\hline Cultivar & $\begin{array}{c}\text { WDS }^{z} \\
\text { injury }(\%)\end{array}$ & $\begin{array}{l}\text { WDS }^{y} \\
\text { index }\end{array}$ & \multicolumn{2}{|c|}{$\begin{array}{c}\text { SPFB }^{\mathrm{x}} \\
\text { injury (\%) }\end{array}$} & $\begin{array}{l}\text { Grubs }^{\mathrm{w}} \\
\text { injury }(\%)\end{array}$ \\
\hline & \multicolumn{2}{|c|}{$1990($ Test 1$)$} & & \\
\hline SC 1149-19 (control) & $67.9 \mathrm{a}^{\mathrm{v}}$ & $1.35 \mathrm{a}$ & \multicolumn{2}{|c|}{$55.7 \mathrm{a}$} & $1.0 \mathrm{~b}$ \\
\hline Regal & $31.3 \mathrm{~d}$ & $0.40 \mathrm{~d}$ & \multicolumn{2}{|c|}{$1.8 \mathrm{~d}$} & $0.1 \mathbf{b}$ \\
\hline Southern Delite & $33.9 \mathrm{~cd}$ & $0.45 \mathrm{~d}$ & \multicolumn{2}{|c|}{$4.5 \mathrm{c}$} & $1.2 \mathrm{~b}$ \\
\hline Jewel & $48.3 \mathrm{~b}$ & $0.72 \mathrm{c}$ & \multicolumn{2}{|c|}{$5.4 \mathrm{c}$} & $1.8 \mathrm{~b}$ \\
\hline Centennial & $59.2 \mathrm{a}$ & $1.01 \mathrm{~b}$ & \multicolumn{2}{|c|}{$4.9 \mathrm{c}$} & $7.2 \mathrm{a}$ \\
\hline Excel & $41.9 \mathrm{bc}$ & $0.49 \mathrm{~d}$ & \multicolumn{2}{|c|}{$13.4 \mathrm{~b}$} & $0.5 \mathrm{~b}$ \\
\hline Resisto & $28.8 \mathrm{~d}$ & $0.34 \mathrm{~d}$ & \multicolumn{2}{|c|}{$9.6 \mathrm{~b}$} & $0.7 \mathrm{~b}$ \\
\hline \multicolumn{6}{|c|}{1991 (Test 2) } \\
\hline SC 1149-19 (check) & $60.0 \mathrm{a}$ & $0.93 \mathrm{a}$ & \multicolumn{2}{|c|}{$32.5 \mathrm{a}$} & $37.2 \mathrm{a}$ \\
\hline Regal & $9.6 \mathrm{~d}$ & $0.12 \mathrm{c}$ & \multicolumn{2}{|c|}{$0.7 \mathrm{~d}$} & $8.3 \mathrm{~b}$ \\
\hline Resisto & $14.8 \mathrm{c}$ & $0.15 \mathrm{c}$ & \multicolumn{2}{|c|}{$6.6 \mathrm{~b}$} & $13.1 \mathrm{~b}$ \\
\hline Centennial & $32.0 \mathrm{~b}$ & $0.36 \mathrm{~b}$ & \multicolumn{2}{|c|}{$4.2 \mathrm{c}$} & $35.1 \mathrm{a}$ \\
\hline \multicolumn{6}{|c|}{ 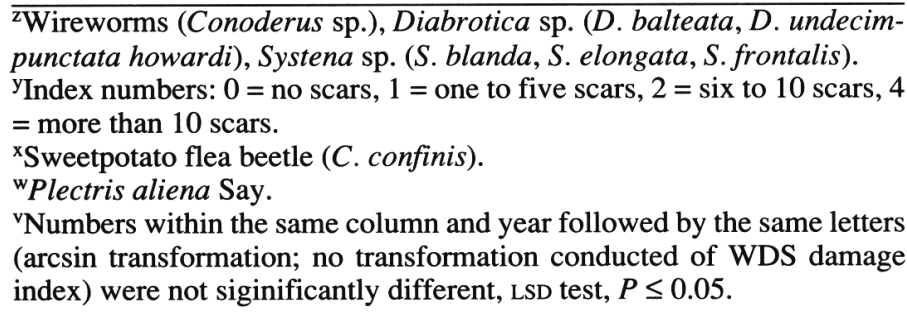 } \\
\hline \multicolumn{6}{|c|}{$\begin{array}{l}\text { controls 'SC 1149-19' and 'Centennial' (Table 2). } \\
\text { Percentage control. The parasitic nematode and fonofos pro- } \\
\text { vided significant percentage field control for all damage categories }\end{array}$} \\
\hline \multicolumn{6}{|c|}{$\begin{array}{l}\text { Table 3. Percentage control of soil insect damage in the field by the appli- } \\
\text { cation of fonofos and a parasitic nematode to sweetpotato cultivars, } \\
1990 \text { and } 1991 \text {. }\end{array}$} \\
\hline & \multicolumn{5}{|c|}{ Control $(\%)^{\mathrm{z}}$} \\
\hline Treatment & WDS $^{y}$ & WD & index & SPFB & Grubs $^{w}$ \\
\hline \multicolumn{6}{|c|}{1990 (Test 1) } \\
\hline Nematode $2.5 b^{\mathrm{v}}$ & $25.5 \mathrm{a}$ & \multicolumn{2}{|c|}{$28.9 \mathrm{a}$} & $36.7 \mathrm{a}$ & $21.4 \mathrm{a}$ \\
\hline Fonofos $^{\mathrm{u}}$ & $17.1 \mathrm{a}$ & \multicolumn{2}{|c|}{$23.5 \mathrm{a}$} & $20.6 \mathrm{a}$ & $31.4 \mathrm{a}$ \\
\hline Control $^{t}$ & $0.0 \mathrm{~b}$ & \multicolumn{2}{|c|}{$0.0 \mathrm{~b}$} & $0.0 \mathrm{~b}$ & $0.0 \mathrm{~b}$ \\
\hline \multicolumn{6}{|c|}{1991 (Test 2) } \\
\hline Nematode $2.5 \mathrm{bb}$ & $13.2 \mathrm{~b}$ & & $9 \mathrm{~b}$ & $27.7 \mathrm{a}$ & $17.6 \mathrm{ab}$ \\
\hline Nematode $7.5 \mathrm{bb}$ & $9.3 \mathrm{bc}$ & & & $17.4 \mathrm{ab}$ & $12.5 \mathrm{ab}$ \\
\hline $\begin{array}{l}\text { Nematode } 2.5 b+ \\
\text { fonofos }\end{array}$ & $42.6 \mathrm{a}$ & & & $28.1 \mathrm{a}$ & $21.0 \mathrm{ab}$ \\
\hline Fonofos & $32.7 \mathrm{a}$ & & & $37.2 \mathrm{a}$ & $30.6 \mathrm{a}$ \\
\hline Control & $0.0 \mathrm{bc}$ & & $.0 \mathrm{~b}$ & $0.0 \mathrm{~b}$ & $0.0 \mathrm{~b}$ \\
\hline
\end{tabular}

$\overline{{ }^{\mathrm{z}} \text { Percent field control }=\mathrm{a}-\mathrm{b} / \mathrm{a} \times 100 ; \mathrm{a}=\text { percentage of damaged roots of }}$ the standard plots and $b=$ percentage of damaged roots of the fonofos $(2.2$ $\mathrm{kg}$ a.i./ha) parasite treatments applied at 2.5 and 7.5 billion/ha ( $2.5 \mathrm{bb}$ and $7.5 \mathrm{bb}$ ). Mean separation within columns and year followed by the same letter (arcsin transformation; no transformation conducted on WDS damage index) are not different by LSD at the 0.05 level for WDS, index, and SPFB; and at 0.05 and 0.09 levels for grubs (1990 and 1991, respectively). 'Wireworm (Conoderus sp.), Diabrotica sp. (D. balteata LeConte, D. undecimpunctata howardi), Systena sp. (S. blanda, S. elongata, S. frontalis). ${ }^{\mathrm{x}}$ Sweetpotato flea beetle (C. confinis).

wPlectris aliena Say.

vNematode applied three times (1990: 2 July, 2 Aug., and 4 Sept.; 1991: 28 June, 26 July, and 26 Aug.) at 2.5 billion and 7.5 billion/ha.

uFonofos at $2.2 \mathrm{~kg}$ a.i./ha applied at planting and at root enlargement (1990: 5 May and 2 July; 1991: 5 May and 9 July).

tNo fonofos or nematode applications.
Table 4. Percent control of soil insect damage for all field treatment combinations (nematode, fonofos) by resistant sweetpotatoes ('Excel', 'Resisto', 'Regal', and 'Southern Delite'), the common cultivars Jewel and Centennial, and the susceptible control 'SC 1149-19 in 1990 and 1991.

\begin{tabular}{lcccr}
\hline \hline & \multicolumn{4}{c}{ Control (\%) } \\
\cline { 2 - 5 } Treatment & WDS $^{\mathrm{y}}$ & WDS $^{\mathrm{y}}$ index & \multicolumn{1}{c}{ SPFB } & Grubs $^{\mathrm{w}}$ \\
\hline & $3990($ Test 1) & & \\
Excel & $37.9 \mathrm{bc}$ & $62.9 \mathrm{~b}$ & $74.6 \mathrm{c}$ & $0.0 \mathrm{~b}$ \\
Regal & $53.4 \mathrm{a}$ & $69.5 \mathrm{ab}$ & $96.4 \mathrm{a}$ & $33.3 \mathrm{a}$ \\
Resisto & $58.4 \mathrm{a}$ & $75.0 \mathrm{a}$ & $82.5 \mathrm{c}$ & $21.2 \mathrm{~b}$ \\
Southern Delite & $49.9 \mathrm{ab}$ & $66.6 \mathrm{ab}$ & $91.5 \mathrm{~b}$ & $0.0 \mathrm{~b}$ \\
Jewel & $29.3 \mathrm{c}$ & $47.3 \mathrm{c}$ & $90.8 \mathrm{ab}$ & $3.9 \mathrm{~b}$ \\
Centennial & $15.3 \mathrm{~d}$ & $25.0 \mathrm{~d}$ & $90.8 \mathrm{ab}$ & $0.0 \mathrm{~b}$ \\
SC 1149-19 (control) & $0.0 \mathrm{e}$ & $0.0 \mathrm{e}$ & $0.0 \mathrm{~d}$ & $0.0 \mathrm{~b}$ \\
& $1991($ Test 2) & & \\
Regal & $84.1 \mathrm{a}$ & $86.6 \mathrm{a}$ & $97.8 \mathrm{a}$ & $72.6 \mathrm{a}$ \\
Resisto & $74.1 \mathrm{~b}$ & $81.2 \mathrm{a}$ & $78.4 \mathrm{~b}$ & $61.8 \mathrm{a}$ \\
Centennial & $43.5 \mathrm{c}$ & $55.4 \mathrm{~b}$ & $84.4 \mathrm{~b}$ & $23.9 \mathrm{~b}$ \\
SC 1149-19 (control) & $0.0 \mathrm{~d}$ & $0.0 \mathrm{c}$ & $0.0 \mathrm{c}$ & $0.0 \mathrm{c}$
\end{tabular}

$\overline{\text { zPercent field control }=a-b / a \times 100 ; a=\text { percentage of damaged roots of }}$ SC 1149-19 and $b=$ percentage of damaged roots of the test cultivar. Mean separation followed by the same letter (arcsin transformation; no transformation conducted on WDS damage index) in columns and year are not different by LSD at the 0.05 level.

'Wireworm (Conoderus sp.), Diabrotica sp. (D. balteata, D. undecimpunctata howardi), Systena sp. (S. blanda, S. elongata, S. frontalis). Index is for WDS.

${ }^{\mathrm{x}}$ Sweetpotato flea beetle (C. confinis).

${ }^{w}$ Plectris aliena Say.

in Test 1 (Table 3). In Test 2, only fonofos reduced WDS damage; however, no differences in SPFB damage were found for fonofos and nematode treatments. Grub control was not affected by nematode or fonofos treatments (Table 3).

Resistant cultivars provided the highest percentage control of WDS and SPFB damage in both tests. Low grub damage ratings in the susceptible cultivars (SC 1149-19, Centennial) made percentage field control for cultivars difficult to assess in Test 1. Grub damage control for 'Regal' and 'Resisto' in Test 2 was higher than for the control 'SC 1149-19' and 'Centennial' (Table 4).

WDS injury was generally lower in the second test, possibly due to variation in insect abundance, insect stages, plant growth, and environmental conditions. With the exception of the susceptible controls, resistance to all insect pests was present in most cultivars. Grub damage, however, was variable from year to year, making the measurement of grub control difficult. For the susceptible control, $30 \%$ to $50 \%$ grub damage is considered significant (J.M.S., unpublished data) for cultivar comparisons-far higher levels than we obtained in Tests 1 or 2 . No interactions were observed between the treatments (nematode, fonofos, or cultivar).

The nematode under laboratory conditions caused high levels of insect mortality. However, nematode effectiveness was poor or variable under field conditions, especially in 1991. This was caused by high soil moisture because the total rainfall over the testing period was $66 \mathrm{~cm}$ in 1991 and $47 \mathrm{~cm}$ in 1992. Kaya (1990) reported that water-saturated soil was detrimental to the parasite because oxygen in the soil was limiting and active movement was impaired. These conditions were also detrimental to soil insects, resulting in nonavailability of the host to the nematode (Kaya, 1990). Soil insect populations of wireworms and Diabrotica species were reduced by $55 \%$ in the second test and may also have 
influenced the efficacy of the nematode due to lower availability for the host. Damage to cultivars in 1991 also was reduced by $60 \%$ for the WDS complex and $40 \%$ for SPFB; however, grub damage increased $89 \%$. The often water-saturated soil in the second test reduced root fresh weights by $54 \%$, which demonstrated the effect of adverse environmental conditions on all biological components of the experiment-plants, insects, and nematodes.

Soil insect damage (percentage of control) in both tests by the use of plant resistance was more effective $(64 \%$ control) than either the nematode $(21 \%$ control) or fonofos $(31 \%$ control) treatments for all categories of insect damage. These results demonstrate the value of using diverse control agents for reducing insect damage in sweetpotatoes.

\section{Literature Cited}

Chalfant, R.B., R.K. Jansson, D.R. Seal, and J.M. Schalk. 1990. Ecology and management of sweetpotato insects. Annu. Rev. Entomol. 35:157180.

Jansson, R.K., S.H. Lecrone, R.R. Gaugh, and G.C. Smart, Jr. 1990 Potential of entomopathogenic nematodes as biological control agents of the sweetpotato weevil (Coleoptera:curculionidae). J. Econ. Entomol. 83:1818-1826.

Jansson, R.K., S.H. Lecrone, and R. Gaugler. 1991. Comparison of single and multiple releases of Heterorhabditis bacteriophora Poinar (Nematoda: Heterorhabditidae) for control of Cylas formicarius Fabricius (Coleoptera: Apionidae). Biol. Control 1:320-328.

Jones, A., J.M. Schalk, and P.D. Dukes. 1979. Heritability estimates for resistance in sweet potato to soil insects. J. Amer. Soc. Hort. Sci. 104:424-426.

Jones, A., P.D. Dukes, J.M. Schalk, M.G. Hamilton, M.A. Mullen, R.A.
Baumgardner, D.R. Paterson, and T.E. Boswell. 1983. 'Resisto' sweet potato. HortScience 18:251-252.

Jones, A., P.D. Dukes, J.M. Schalk, M.G. Hamilton, M.A. Mullen, R.A. Baumgardner, D.R. Paterson, and T.E. Boswell. 1985. 'Regal' Sweet Potato. HortScience 20:781-782.

Jones, A., P.D. Dukes, J.M. Schalk, M.G. Hamilton, and R.A. Baumgardner. 1987a. 'Southern Delite' sweet potato. HortScience 22:329-330.

Jones, A., J.M. Schalk, and P.D. Dukes. 1987b. Control of soil insect injury by resistance in sweetpotato. J. Amer. Soc. Hort. Sci. 112: 195197.

Jones, A., P.D. Dukes, J.M. Schalk, and M.G. Hamilton. 1989. 'Excel' sweet potato. HortScience 24:171-172.

Kaya, G. 1990. Ecology, p. 93-115. In: R. Gaugler and H.K. Kaya (eds.). Entomopathogenic nematodes in biological control. CRC Press, Boca Raton, Fla.

Schalk, J.M. 1984. Multiple insect resistance in sweet potato. Proc. Sweet Potato Weevil Wkshp. Southeastern Branch Entomol. Soc. Amer., 24 Jan. 1984. New Orleans. p. 56-65.

Schalk, J.M. and A. Jones. 1985. Major insect pests, p. 59-78. In: J.L. Bouwkamp (ed.). Sweet potato products: A natural resource for the tropics. CRC Press, Boca Raton, Fla.

Schalk, J.M., A. Jones, and P.D. Dukes. 1986. Factors associated with resistance in recently developed sweet potato cultivars and germplasm' to the banded cucumber Diabrotica balteata LeConte. J. Agr. Entomol 3:329-334.

Schalk, J.M. 1986. Rearing and handling of Diabrotica balteata, p. 49-50. In: J.L. Krysan and T.L. Miller (eds.). Methods for the study of pest Diabrotica. Springer-Verlag, New York.

Schalk, J.M., A. Jones, P.D. Dukes, and J.K. Peterson. 1991. Approaches to the control of multiple insect problems in sweet potato in the southern U.S., p. 283-301. In: R.K. Jansson and K.V. Raman (eds.). Sweetpotato pest management, a global perspective. Westview, Boulder, Colo. 